\title{
TROSKA O ZEWNĘTRZNE BEZPIECZEŃSTWO ODRODZONEGO PAŃSTWA POLSKIEGO
}

\author{
Marian Leczyk, \\ Polska i sasiedzi. Stosunki wojskowe 1921-1939, \\ Warszawa 2004, s. 453.
}

Książka wymieniona w tytule niniejszej recenzji została przygotowana przez profesora zwyczajnego Mariana Leczyka, wybitnego znawcę najnowszych dziejów politycznych, zwłaszcza spraw dotyczących dyplomacji oraz problematyki wojskowej.

Rozważania podejmowane przez profesora Leczyka, poprzedzone obszernym wstępem i uwieńczone zakończeniem oraz dokładnym indeksem osobowym, zostały przedstawione w trzech rozbudowanych rozdziałach. Takie ujęcie konstrukcyjne okazało się niezwykle trafne. Budzi nawet skojarzenia skierowane ku różnym klasycznym utworom i opracowaniom. O wysokiej ocenie opracowania zaprezentowanego przez profesora Mariana Leczyka zadecydowało jednak przede wszystkim to, że autor porusza bardzo ważny fragment dyplomatycznych i militarnych dziejów narodu polskiego, a na podstawie obfitych przekazów materiałowych formułuje nadzwyczaj trafne wnioski i głębokie oceny.

Opracowanie Mariana Leczyka zostało oparte na szerokiej podstawie źródłowej - archiwalnej. Autor tego dzieła wykorzystał również skrupulatnie różne opracowania monograficzne i syntetyczne, a także studia oraz artykuły, niekiedy nawet całkiem drobne, zamieszczone w rozlicznych czasopismach i wydawnictwach zbiorowych, a zawierające jakieś ważkie informacje. 
Wśród wykorzystanych opracowań widziałbym także dwie dość ważne publikacje, wiążące się pośrednio z podjętym tematem. Chodzi o wspomnienia Stanisława Srokowskiego, który w pierwszej połowie trzeciego dziesięciolecia XX wieku był polskim konsulem w Prusach Wschodnich i w swojej książce poświęcił sporo miejsca sprawom związanym z tajnymi poczynaniami Niemiec, dążących do przezwyciężenia wersalskich ograniczeń militarnych ${ }^{1}$. Wypada tu ponadto dodać, że materiały i papiery zgromadzone przez profesora Srokowskiego są przechowywane w zasobach Archiwum Polskiej Akademii Nauk w Warszawie.

Na uwagę zasługuje również książka Hermanna Rauschninga, był bowiem znanym działaczem partii nazistowskiej (NSDAP) i w latach 1933-1934 funkcjonował jako przewodniczaccy Senatu w Wolnym Mieście Gdańsku. Już w 1934 roku zerwał jednak z hitleryzmem, wyemigrował do Stanów Zjednoczonych i opublikował książkę, w której obnażył dokładnie gigantyczne plany podbojów planowanych przez Hitlera i wspierających go paladynów, a także scharakteryzował perfidne metody działań na rzecz tych na pozór obłędnych i nierealnych dążeń ${ }^{2}$.

W charakterystyce podstawy źródłowej monografii na wyraźne podkreślenie zasługuje fakt, iż autor dotarł do licznych publikacji źródłowych, a także wykorzystał wyjątkowo starannie dokumentację, która znajduje się w zasobach Archiwum Akt Nowych (AAN) oraz w zespołach Centralnego Archiwum Wojskowego (CAW), w zespołach zdekompletowanych silnie $\mathrm{w}$ wyniku powojennych perturbacji i zachowanych tylko w stanie szczątkowym. Nic zatem dziwnego, że profesor Leczyk napomyka tu i ówdzie o niedostatku odpowiednich, bardziej szczegółowych archiwalnych przekazów materiałowych w odniesieniu do różnych poruszanych przez niego kwestii.

Pomimo wspomnianych luk materiałowych profesor Leczyk zdołał odtworzyć w sposób niezwykle rzetelny zasięg oraz wyniki intensywnych zabiegów, które podejmowali w latach II Rzeczypospolitej polscy attaché wojskowi w krajach sąsiadujących z Polską, aby zapewnić bezpieczną egzystencję państwa polskiego. W toku rozważań, ujętych w rozdziale pierwszym, obejmującym wydarzenia od początku 1921 roku do jesieni 1925 roku, Marian Leczyk wyeksponował te kwestie, które były związane ściśle z zasadami oraz funkcjonowaniem przymierzy polityczno-wojskowych, zawartych przez

1 S. Srokowski, Prusy Wschodnie, Warszawa 1945.

2 H. Rauschning, Rewolucja nihilizmu (tłumaczenie na język polski), Warszawa 1939. 
państwo polskie z Francją i Rumunią. Dokonał też licznych nowych ustaleń faktograficznych, że nie sposób ich wyliczyć w niniejszych uwagach recenzyjnych. Na szczególną wzmiankę zasługują jednak te ważkie konstatacje, które dotyczą współdziałania Niemiec i sowieckiej Rosji, opartego na ściśle tajnych uzgodnieniach. Chodzi o wstępną niemiecko-sowiecką konwencję wojskową, podpisaną już 25 marca 1921 roku. Umowa ta była następnie potwierdzona i została ujęta w sposób bardziej szczegółowy 3 kwietnia 1922 roku, a więc o dwa tygodnie wcześniej, niż osławiony niemiecko-sowiecki traktat polityczny, podpisany 16 kwietnia tegoż roku w Rapallo.

Autor rozprawy wykazał w sposób gruntowny ograniczoną wartość sojuszy, zawartych przez Polskę z Francją i Rumunią, a jednocześnie podkreślił, że Polska nie miała możliwości pozyskania lepszych, to znaczy bardziej wiarygodnych sprzymierzeńców. Brak takich możliwości uzewnętrzniły na przykład daremne zabiegi na rzecz utworzenia Związku Bałtyckiego, obejmującego Polskę sprzymierzoną z Rumunią oraz Finlandię, Estonię i Łotwę. Realizację zamysłów związanych z zacieśnieniem pożądanego współdziałania, jak to Marian Leczyk wykazał na podstawie wiarygodnych przekazów materiałowych, uniemożliwiał nie tylko polsko-litewski konflikt o Wilno. Istotną przeszkodą okazała się postawa innych państw bałtyckich. Zachowywały one daleko idącą ostrożność w rozmowach dotyczących zacieśnienia związków z Polską, bo obawiały się odwetu ze strony Niemiec i sowieckiej Rosji. Ostrożność państw bałtyckich wynikała ponadto z niewiary w odpowiednio duże militarne możliwości państwa polskiego.

W tym okresie, pomimo intensywnego współdziałania Rosji i Niemiec, ani Polska, ani też państwa bałtyckie nie odczuwały zresztą jakiegoś bezpośredniego zagrożenia ze strony obydwu potencjalnych przeciwników. Ten względny spokój, jak stwierdza profesor Leczyk, nie eliminował jednak czujności polskich środowisk politycznych i wojskowych, ponieważ wywiad polski funkcjonował sprawnie i gromadził wiele niepokojących informacji o rozmiarach politycznego, ekonomicznego i wojskowego współdziałania Niemiec oraz sowieckiej Rosji. Zasługą autora monografii jest odtwarzanie (najpełniej w polskiej literaturze naukowej) obrazu współpracy zwłaszcza w dziedzinie lotnictwa oraz broni pancernej i chemicznej.

Polski aparat wojskowy podejmował zabiegi mające na celu zewnętrzne wzmocnienie obronności państwa polskiego. Wiele uwagi poświęcano, między innymi, kwestiom związanym z zapewnieniem dostaw materiałowych wojskowych z zagranicy. Chodziło o zabezpieczenie szlaków transportowych wiodących z kierunku południowego, to znaczy od portów usytuowanych na wybrzeżu akwenów Morza Czarnego i Morza Śródziemnego. 
Poważną zmianę sytuacji politycznej, a także militarnej, w jakiej znajdowała się Polska, przyniosły następnie postanowienia podjęte na konferencji w Locarno (5-16 października 1925 roku). Chodzi tu, rzecz jasna, o gwarancje dotyczące trwałego zabezpieczenia granic w Europie Zachodniej. W odniesieniu do wschodnich i południowo-wschodnich granic państwa niemieckiego (granice z Polską i Czechosłowacją) nie zostały natomiast zastosowane odpowiednie międzynarodowe gwarancje.

Od czasów Locarno zaznaczał się też proces stopniowego rozluźnienia sojuszniczych związków polsko-francuskich, a współdziałanie sojusznicze z Rumunią, jak słusznie zauważył Marian Leczyk, nie miało nadal dostatecznej wartości. Rumuński sprzymierzeniec nie dysponował odpowiednim potencjałem militarnym, ani też dobrze wyszkoloną armią. Poważne zaniedbania organizacyjne rumuńskich sił zbrojnych, a także ich liche uzbrojenie i wyposażenie budziły niepokój polskich kół wojskowych. Sprawy te zostały szeroko i kompetentnie omówienie w książce profesora Leczyka.

Autor konstatuje też pogorszenie bezpieczeństwa Polski po ewakuacji wojsk koalicyjnych z okupowanych obszarów nad Renem w 1930 roku. Jest tu wiele trafnych i oryginalnych spostrzeżeń. Z żywotnymi interesami państwa polskiego nie pokrywało się również to, że sztabowcy francuscy zaczęli się opowiadać od połowy lat dwudziestych za obronną doktryną przyszłych działań militarnych. Tym pasywnym zamysłom towarzyszyły też odpowiednie zmiany organizacyjne, zachodzące $\mathrm{w}$ armii francuskiej. Zmiany te, co Marian Leczyk wyraźnie podkreśla, były w Polsce obserwowane z narastającym zaniepokojeniem. Przykładem tego zaniepokojenia są sprawy związane z linią Maginota. Francja przystąpiła w 1929 roku do budowy i rozbudowy swoich umocnień pogranicznych. To wielkie przedsięwzięcie pochłaniało ogromne środki finansowe. Wywierało jednak ujemny wpływ na proces rozbudowy tych francuskich sił zbrojnych, które powinny zachowywać zdolność podejmowania szeroko zakrojonych działań ofensywnych. Francja szukała z jednej strony zabezpieczenia opartego na papierowych gwarancjach, a z drugiej strony na żelbetonowych obwarowaniach. W razie konfliktu zbrojnego zamierzała się schronić za taką podwójną gardą, co nie rokowało niczego dobrego Polsce jako sprzymierzeńcowi tak zachowującego się mocarstwa.

W tej sytuacji - zauważa autor monografii - koła odpowiedzialne za bezpieczeństwo państwa polskiego zaczęły sobie uświadamiać, że, być może, trzeba będzie liczyć w większym stopniu na własne siły i na jakieś inne strategiczne rozwiązania. W toku ich poszukiwań doszło do podpisania układów z potężnymi sąsiadami państwa polskiego, a mianowicie paktu o nieagresji 
z ZSRR (25 lipca 1932 roku) i deklaracji o nieagresji z Niemcami (26 stycznia 1934 roku). Fakt podpisania tych układów nie był ze strony polskiej przejawem naiwności, chodziło bowiem, między innymi, o zyskanie czasu, umożliwiającego militarne wzmocnienie państwa. Zawarcie paktu z III Rzeszą spowodowało jednak znaczne oziębienie w stosunkach polsko-francuskich, ponieważ w Paryżu utrzymywało się podejrzenie, że mogło też dojść do jakichś tajnych polsko-niemieckich uzgodnień dotyczących wzajemnego współdziałania. Dyplomacja polska usiłowała rozproszyć te bezpodstawne obawy, ale nieufność strony francuskiej miała trwały charakter.

Od 1935 roku, w stosunkach polsko-francuskich, jak stwierdza autor, zaczęła się zaznaczać ponowna, stopniowa poprawa. Tym korzystnym zmianom sprzyjały wzajemne wizyty dyplomatyczne. Istotną rolę odgrywało również to, że 6 września 1936 roku Francja zdecydowała się na podpisanie umowy w Rambouillet, na podstawie której Polska miała otrzymać dogodny kredyt w wysokości 2 miliardów franków, przeznaczonych głównie na wzmocnienie polskiej obronności. W tym okresie zaznaczało się natomiast coraz większe rozluźnienie polsko-rumuńskich stosunków sojuszniczych, co zostało poddane pogłębionej analizie przez profesora Leczyka.

Na zakończenie niniejszych uwag wypada podkreślić, że książka profesora Mariana Leczyka została wyposażona w godny uznania aparat naukowy. Ta uwaga dotyczy nie tylko rozmiarów tego aparatu, bo do jego zalet należy zaliczyć również to, że odsyłacze do dokumentów czerpanych z archiwaliów i z publikacji są formułowane w tradycyjny, to znaczy w solidny sposób. Na specjalne podkreślenie zasługuje precyzyjny, logiczny tok rozważań wyposażonych - jak to zostało już zaznaczone - w nowe bardzo obfite ustalenia faktograficzne. Do zalet tej cennej publikacji należy zaliczyć także jasność ujęcia stylistycznego. Lektura tej książki przynosi czytelnikowi prawdziwą satysfakcję. 